\section{CARTA DE LOS EDITORES}

Coincidiendo con el cuarto aniversario de la fundación de la revista Ius et Scientia nos complace presentar el número 2/2018 bajo el título: "Epigenética, transhumanismo y grupos vulnerables". Este número es, además, el resultado del exitoso Congreso Internacional que, con el mismo título, tuvo lugar en la Facultad de Derecho de la Universidad de Sevilla el pasado 19 de octubre de 2018. En este foro interdisciplinar coincidieron juristas, filósofos, médicos y científicos especializados en epigenética que durante una fructífera jornada debatieron e intercambiaron conocimientos y puntos de vista complementarios sobre una materia de común interés y de enorme relevancia para la sociedad contemporánea, también denominada como la "sociedad de las nuevas tecnologías", o la sociedad global del riesgo en la que se está produciendo un evidente cambio de paradigma ético-cultural que se encamina hacia lo que Ulrich Beck se refirió en su libro póstumo como "la metamorfosis del mundo".

Ante este evidente cambio de paradigma cabe preguntarse: ¿Ha pasado la hora de la humanidad? ¿Estamos acaso ante un momento auroral del posthumanismo? Y en esa hipotética nueva era (New Age) en la que humanos y posthumanos convivirán en un mundo domeñado por la IA y las máquinas superinteligentes, ¿qué le deparará el futuro a nuestra especie? Parece indudable que, desde un plano epistemológico, en el último siglo, el antropocentrismo (la doctrina que defiende que el hombre es el centro y la medida de todas las cosas) ha ido cediendo cada vez más espacio al tecnocentrismo (en cuya visión integrista de la realidad se percibe el desarrollo tecnológico como la única respuesta y la solución a todos los problemas). Con esta pérdida de peso del legado humanista heredado del Renacimiento y la Ilustración, se ha ido resquebrajando también la confianza en los valores supremos, los principios universales y los ideales liberales que lo inspiraron.

En esta época en la que el individuo vive mecanizado, absorbido por la tecnología, enajenado en el mundo de lo virtual, consumiendo - en su particular "huida de lo cotidiano" (Broncano)- gran parte de su tiempo consultando las múltiples aplicaciones de sus teléfonos inteligentes, relacionándose con personas desconocidas a través de redes sociales como Facebook, Twitter e Instagram, o incluso creándose un avatar en juegos que reproducen una doble vida donde nuestro personaje virtual posee todas las cualidades de las que carece nuestro yo real, tal vez sería oportuno recuperar al menos parte del optimismo antropológico

\section{LETTER FROM THE EDITORS}

Coinciding with the fourth anniversary of the founding of the e-journal Ius et Scientia, we are pleased to present the number 2/2018 under the title: "Epigenetics, Transhumanism and Vulnerable Groups". This number is also the result of the successful International Congress that, with the same title, took place in the Faculty of Law of the University of Seville on October 19, 2018. In this interdisciplinary forum, many jurists, philosophers, doctors and scientists who are specialist in Epigenetics, debated and exchanged knowledge and complementary points of view on subjects of common interest and of enormous relevance for contemporary society, also known as the "society of new technologies", or "the global society of the risk" in which an evident change of ethical-cultural paradigm is taking place that is heading towards what Ulrich Beck referred to in his posthumous book as "The metamorphosis of the world".

Faced with this obvious paradigm shift, it is worth asking: Has the hour of humanity passed? Are we facing an auroral moment of Posthumanism? And in that hypothetical new era (New Age) in which humans and posthumans will coexist in a world tamed by AI and superintelligent machines, what will the future hold for our species? It seems unquestionable that, from an epistemological level, in the last century, Anthropocentrism (the doctrine that defends that man is the center and the measure of all things) has been giving more and more space to Technocentrism (in whose fundamentalist vision of the reality is perceived as technological development as the only answer and solution to all problems). With this loss of weight of the humanist legacy inherited from the Renaissance and the Enlightenment, trust in the supreme values, the universal principles and the liberal ideals that inspired it, have also been cracking.

In this era in which the individual lives mechanized, absorbed by technology, alienated in the world of the virtual, consuming - in his particular "flight from the everyday" (Broncano) - a large part of his time consulting the multiple applications of his smartphones, interacting with unknown people through social networks like Facebook, Twitter and Instagram, or even creating an avatar in games that reproduce a double life where our virtual character possesses all the qualities that our real self lacks, maybe it would be opportune to recover at least part of the anthropological optimism that the great humanists and enlightened people like Immanuel Kant shared. Indeed, the philosopher-political work of Königsberg expressed his confidence in the moral progress of the human race (which may be interrupted occasionally, but never stopped definitively). This Kantian trust in the human being is justified in the fact that, in his opinion, the individual 
que compartían los grandes humanistas e ilustrados como Immanuel Kant. En efecto, el pensador de Königsberg expresó en su obra filosófico-política su confianza en el progreso moral del género humano (que podrá interrumpirse ocasionalmente, pero nunca detenerse definitivamente). Esta confianza kantiana en el ser humano se justifica en el hecho de que, a su juicio, el individuo descubre su condición de ser humano y de sujeto moral a un mismo tiempo; es decir, tiene la seguridad de que, al menos como miembro del género humano, su progreso moral está garantizado.

Ningún obstáculo debería haber para que el hombre expanda libremente su conocimiento de la naturaleza y del universo en el que habita; ningún impedimento tendría que impedirle el desarrollo del dominio de la tecnología para mejorar sus condiciones de vida y sus capacidades naturales; pero para llevar a cabo este propósito evolutivo que es consustancial a la propia especie humana, no sirve cualquier proyecto, y menos aún aquellos planteamientos que se inspiran en ideologías negadoras de la sacralidad del ser humano y al reconocimiento de su dignidad como sujeto moral. A fin de cuentas, la propuesta de un programa de progreso tecnológico que ignore el concepto kantiano del ser humano como fin en sí mismo, y que se lleve a cabo a costa de la instrumentalización del individuo, esconderá en realidad un proyecto antihumanista que, lejos de liberar a la humanidad, solo contribuirá a encadenar y someter a los hombres -como en el pasado- a una nueva tiranía: el despotismo antiilustrado de la tecnocracia posthumanista.

Partiendo de este común punto de vista el presente número reúne un cuerpo de artículos y una recensión en la que se abordan cuestiones centrales referentes a la epigenética, el transhumanismo (que afecta a diferentes ámbitos de la medicina genética, la biogenética, la Inteligencia Artificial y la robótica) y la vulnerabilidad humana. En el primer artículo, que se ocupa del estudio de la adaptación humana al cambio climático desde una perspectiva bioética y biojurídica internacional, sus autores (Simona Fanni y Ernani Contipelli) evocan el papel clave de los Estados, definidos como "agentes primarios" en la realización de los derechos humanos, en lo que respecta a la intersección del bioderecho y cambio climático.

En el segundo artículo, Santiago Álvarez Carreño lleva a cabo un estudio evolutivo de recientes normas ambientales españolas que parecen confirmar la tendencia hacia la reducción de los niveles de protección ambiental logrados antes de la crisis financiera surgida a partir de 2008. Esta tendencia, nos discovers his condition as a human being and as a moral subject at the same time; that is to say, he is sure that, at least as a member of the human race, his moral progress is guaranteed.

No obstacle should exist for man to freely expand his knowledge of nature and the universe in which he lives; no impediment would have to prevent him from developing the domain of technology to improve his living conditions and his natural abilities; but to carry out this evolutionary purpose that is consubstantial to the human species itself, any project does not help, and even less those approaches that are inspired by ideologies that negate the sacredness of the human being and the recognition of their dignity as a moral subject. Ultimately, the proposal of a technological progress program that ignores the Kantian concept of the human being as an end in itself, and that is carried out at the expense of the instrumentalization of the individual, will hide in reality an anti-humanist project that, far away to liberate humanity, it will only contribute to chaining and subjecting men - as in the past - to a new tyranny: the antienlightened despotism of the Posthumanist Technocracy.

Starting from this common point of view, this issue brings together a set of articles and a review in which central issues are addressed to Epigenetics, Transhumanism (which affects different areas of Genetic Medicine, Biogenetics, Artificial Intelligence and Robotics) and Human Vulnerability.

In the first article, which deals with the study of human adaptation to climate change from an international bio-legal and bio-juridical perspective, its authors (Simona Fanni and Ernani Contipelli) evoke the key role of States, defined as "primary agents" in the realization of human rights, with respect to the intersection of biolaw and climate change.

In the second article, Santiago Álvarez Carreño carries out an evolutionary study of recent Spanish environmental regulations that seem to confirm the trend towards the reduction of the levels of environmental protection achieved before the financial crisis that began in 2008. This tendency alerts us to this author, puts at risk the protection of the environment, and especially the vulnerable groups of people most exposed and harmed by this deterioration of protection standards.

The study of the genetic factors that are determined by the cellular environment, as well as the analysis of chemical reactions and other processes that modify the activity of DNA but without altering its sequence, deals with Epigenetics. Precisely, to clarify the key concepts of Epigenetics, Sabrina Rivero Canalejo dedicates her interesting article entitled "What is Epigenetics?"

In line with the previous article on Epigenetics, Susana Álvarez de Neyra Kappler dedicates her article to explain 
alerta este autor, pone en riesgo la protección del medioambiente, y muy especialmente a los grupos vulnerables de personas más expuestas y perjudicadas por este deterioro de los estándares de protección.

Al estudio de los factores genéticos que son determinados por el ambiente celular, así como del análisis de las reacciones químicas y demás procesos que modifican la actividad del ADN pero sin alterar su secuencia se ocupa la epigenética. Precisamente, a aclarar los conceptos claves de la epigenética dedica precisamente Sabrina Rivero Canalejo su interesante artículo titulado "¿Qué es la epigenética?".

En línea de continuidad con el anterior artículo sobre epigenética, Susana Álvarez de Neyra Kappler dedica su artículo a explicarnos uno de los principales avances, "última revolución de los laboratorios forenses": el fenotipado forense, técnica forense de la criminalística que pretende predecir el aspecto humano a partir de una muestra de ADN hallada en la escena de un crimen.

En relación con la vulnerabilidad humana debida a la exposición humana a los cambios ambientales (una de las principales causas de la metamorfosis del mundo a la que nos referimos antes), Blanca Soro Mateo reclama en su artículo una reformulación de las herramientas jurídicas al servicio de la protección ambiental y de la salud de las personas en clave de derechos humanos.

A propósito del acceso a la información que afecta a los grupos vulnerables, es decir, en relación con el derecho a la información de estos colectivos humanos en materia de salud frente a la declaración de información clasificada para evitar escándalos políticos, María Dolores Mateo Alcaraz somete a balance ético los argumentos de la razón política frente a los de la razón jurídica.

El séptimo trabajo monográfico, escrito por Jorge Castellanos Claramunt, se centra en el transhumanismo y las nuevas tecnologías que pretenden superar los límites de la naturaleza y de su lotería aleatoria por el dominio de la inteligencia artificial y de los algoritmos. Este avance tecnológicocientífico promete una extensión de la vida y un mejoramiento de las capacidades y de las cualidades humanas, hasta el punto de plantear la creación de una nueva especia posthumana. Estos avances, sin embargo, ponen en peligro la idea de igualdad entre los hombres, pues en ese escenario distópico que los gurús del posthumanismo imaginan, hay una especie (la humana) que estaría sometida a otra (la one of the main advances, "latest revolution of forensic laboratories": forensic phenotyping, forensic technique of criminalistics that aims to predict the appearance human from a DNA sample found at the scene of a crime.

In relation to human vulnerability due to human exposure to environmental changes (one of the main causes of the metamorphosis of the world to which we referred earlier), Blanca Soro Mateo claims in her article a reformulation of legal tools at the service of the environmental protection and the health of the people in the key of human rights.

With regard to access to information that affects vulnerable groups, that is, in relation to the right to information of these human groups in health matters in relation to the declaration of classified information to avoid political scandals, María Dolores Mateo Alcaraz submits to the ethical balance the arguments of the political reason against those of the legal reason.

The seventh monographic work, written by Jorge Castellanos Claramunt, focuses on Transhumanism and new technologies that aim to overcome the limits of nature and its random lottery by mastering artificial intelligence and algorithms. This technological-scientific advance promises an extension of life and an improvement of human capacities and qualities, to the point of proposing the creation of a new post-human spice. These advances, however, jeopardize the idea of equality between men, because in that dystopian scenario that Posthumanism gurus imagine, there is one species (the Human) that would be subject to another (the Posthuman).

Another threat that is most convulsive in the contemporary world is that which constitutes bioterrorism or new generation terrorism. The study of its characteristics, typology, causes and possible consequences is based on the study of Saad Bentaouet, whose scientific contribution is essential for States, international organizations and the scientific community to become aware of this global threat.

From a forensic perspective and medical field analysis Dr. Rogelio Garrido Teruel studies the causes of the high mortality of sub-Saharan women during pregnancy and childbirth. The high maternal mortality in Sub-Saharan Africa is, precisely, one of the main Millennium Development Goals, multiplying the number of deaths by a hundred compared to the mortality rate in developed countries.

With regard to this humanistic and global perspective from which the problems that are integrated in the field of Epigenetics, Transhumanism and Human Vulnerability are addressed in this issue, Anna Piazza appeals to a science of ends that uses the Thomistic doctrine of common benefit. 
posthumana).

Otra de las amenazas que más está convulsionando el mundo contemporáneo es la que constituye el bioterrorismo o terrorismo de nueva generación. Al estudio de sus características, tipología, causas y posibles consecuencias dedica su original estudio Saad Bentaouet, cuya contribución científica se nos antoja esencial para que los Estados, las organizaciones internacionales y la comunidad científica tomen conciencia de esta amenaza global.

Desde una perspectiva forense y de análisis médico de campo el Dr. Rogelio Garrido Teruel estudia las causas de la elevada mortalidad de las mujeres subsaharianas durante la gestación y el parto. La elevada mortalidad materna en el África Subsahariana constituye, precisamente, uno de los principales Objetivos del Milenio, pues multiplica por cien el número de muertes en comparación con la tasa de mortalidad de los países desarrollados.

A propósito de esta perspectiva humanista y global desde la que se abordan en este número los problemas que se integran en el ámbito de la epigenética, el transhumanismo y la vulnerabilidad humana, Anna Piazza apela a una ciencia de los fines que utiliza la doctrina tomista del bien común.

Desde una perspectiva global y sensible hacia los derechos humanos de las minorías étnicas Jinyup Kim denuncia la explotación de los recursos de los pueblos indígenas a cargo de las grandes corporaciones multinacionales, que realizan a su juicio actos de auténtica biopiratería sobre sus tierras. Al mismo tiempo, el autor explica las claves de los principales instrumentos jurídicos internacionales dirigidos a contrarrestar estos actos de biopiratería (con especial atención al Convenio sobre la Diversidad Biológica).

Finalmente, el número se cierra con una nueva sección dedicada al comentario de libros recientes, en este caso, publicamos la recensión de Ramón Darío Valdivia Giménez al libro que recientemente ha publicado Fernando H. Llano Alonso sobre los límites ético-jurídicos de transhumanismo: Homo excelsior (Tirant lo Blanch, 2018).

Disponemos de originales de extraordinario interés científico que serán publicados en el próximo número (1/2019), en aras de la homogeneidad de los contenidos del actual número que ahora sometemos al juicio crítico de nuestros distinguidos lectores.
From a global and sensitive perspective towards the human rights of the ethnic minorities, Jinyup Kim denounces the exploitation of the resources of the indigenous peoples in charge of the big multinational corporations, which in their opinion acts of authentic Biopiracy on their lands. At the same time, the author explains the keys of the main international legal instruments aimed at counteracting these acts of Biopiracy (with special attention to the Convention on Biological Diversity).

Finally, the number closes with a new section dedicated to the commentary of recent books, in this case, we publish the review of Ramón Darío Valdivia Giménez to the book that has recently published Fernando H. Llano Alonso on the ethical-juridical limits of transhumanism: Homo excelsior (Tirant lo blanch, 2018).

We have originals of extraordinary scientific interest that will be published in the next issue (1/2019), for the sake of the homogeneity of the contents of the current issue that we now submit to the critical judgment of our distinguished readers. 